\title{
Hair Dyeing Properties Using Extracts of Wild Grape (Vitis coignetiae)
}

Yun-Yeong Choi, Chul-Ho Park

Department of Cosmetology Sciences, Nambu University, Gwangju, Korea

"Corresponding author: Chul-Ho Park, Department of Cosmetology Sciences, Nambu University, 23 advanced Jungang-ro, Gwangsan-gu, Gwangju 62271, Korea

Tel.: +82 629700140

Fax: +82 629700140

E-mail: chpark@nambu.ac.kr

Received July 18, 2016

Revised August 22, 2016

Accepted September 9, 2016

Published September 30, 2016

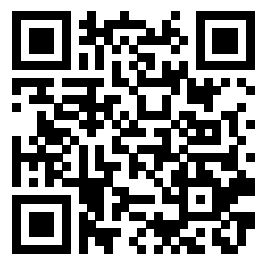

\begin{abstract}
Purpose: The purpose of this study is to examine the possibility of using anthocyanin pigments from wild grapes. Methods: Anthocyanin concentration was determined by measuring the absorbency of anthocyanin in wild grapes at 540 $\mathrm{nm}$. Color changes were observed according to changes in temperature, time, and $\mathrm{pH}$ by color measurement. Results: The most effective conditions for hair dyeing using anthocyanin pigments was at $25^{\circ} \mathrm{C}$ for $40 \mathrm{~min}$. Unmordanted hair increased the dye intake $(\mathrm{K} / \mathrm{S})$ with increased dyeing temperature, and hair color changed from dark to bright red. Anthocyanin pigments are especially sensitive to $\mathrm{pH}$, and dye intake decreased with increased $\mathrm{pH}$. Higher acidity generally led to a stronger reddish tint, while higher alkalinity led to a decrease in red coloration and a stronger yellow tint. When dyeing hair, pre-, simultaneous-, and post-mordanting should be selected with consideration of the characteristics of the mordants themselves (dye intake, lightless, chroma, and color). Based on $\mathrm{K} / \mathrm{S}$ only, pre-mordanting was effective for $\mathrm{FeSO}_{4}, \mathrm{MgSO}_{4}, \mathrm{Na}_{2} \mathrm{CO}_{3}, \mathrm{MnSO}_{4}$, and $\mathrm{Co}\left(\mathrm{NO}_{3}\right)_{2}$; simultaneous mordanting was effective for $\mathrm{CuSO}_{4}, \mathrm{CH}_{3} \mathrm{COOH}$, and $\mathrm{CaCO}_{3}$; and post-mordanting was effective for $\mathrm{AlK}\left(\mathrm{SO}_{4}\right)_{2}$. The rate of colorfastness decreased with repeated shampooing. Conclusion: Extracts from wild grapes may be useful as a hair dye.
\end{abstract}

Keywords: Wild grape, Dyeing, Anthocyanin, Mordant, Colorfastness to washing

\section{Introduction}

모발염색은 아름다워지고자 하는 욕구와 더불어 자신의 개성을 표현하는 수단으로 사용된다. 모발염색에 사용되는 영구염모제는 장시간 발색이 안정되고, 다양한 색조를 얻을 수 있다는 이유로 가 장 많이 사용되고 있다(Kang \& Kim, 2008). 그러나 인간의 두부 에 직접 시술하는 모발염색분야에서는 영구염모제에 들어있는 파 라페닐렌디아민( $p-$ phenylenediamine, PPD)이 반복 사용시 피부 발진, 습진, 두피에 염증을 유발하여 알레르기성 접촉피부염을 일으키 며, 심한 경우 얼굴이 부어 오르고 동통성 타박상이 발생하거나가려움 증, 안구통증, 시력 손상, 두피질환 및 탈모 등 부작용을 유발한다. 암 모니아의 경우 현기증이나 눈 자극 및 모발의 수분을 파괴해서 모발이 푸석해지고 끊어지는 등의 인체 부작용을 일으키고 염색 후 남은 염색 제와 염색용기를 통한 환경오염이 문제시되었다(Lee \& Park, 2012).

천연염료는 매염제를 사용함으로써 다양한 명도와 채도의 색상
변화를 줄 수 있으며(Choi \& Kim, 2004), 인체에 무해하면서도 환 경을 오염시키지 않아(Ali et al., 2009) 합성염모제의 대안으로 연 구되고 있다.

천연염료 중 안토시아닌 색소는 산화방지 작용이 월등해 체세포 를 보호하고 면역체계를 증진하고(Hou, 2003; Noda et al,, 2002; Tsuda et al., 1996; Wang et al., 1999), 항암작용(Bomser et al., 1996; Kamei et al., 1995; Nagase et al., 1998; Shin et al., 2009) 에도 효과가 있으며, 조건에 따라 다양한 색깔을 표현할 수 있어 다 색성 염료(Kim \& Park, 2014; Seo \& Park, 2015; Shin \& Park, 2014; Lee \& Park, 2012; Jang \& Park, 2015; Hong \& Park, 2013)로 연구가 활발해지고 있는 실정이다.

머루(Vitis coignetiae, wild grape)는 갈매나무목 포도과에 속하 는 낙엽성 덩굴식물로 동북아시아, 중국, 일본 및 한국에서 자생하 고 있으며, 포도와 형상이 비슷하나 산이나 야생으로 자생하며 내 한성과 병충해 저항성이 강한 성질을 지녔으며, 이러한 특성을 이 
용하여 기온이 낮아 포도재배가 곤란한 경기도 지역과 지리산 지 역에서 재배되고 있다(Jung \& Moon, 2005). 열매에는 phenolic acids, flavonoids와 같은 페놀 화합물과 플라보노이드, 안토시 아닌 등의 기능성 색소가 다량 함유되어 있다(Kim, 1996). 과피 및 종자 추출물은 항산화(Kim et al., 2005; Park, 2011a; Park, 2011b; Bing et al., 2015; Won, 2009; Jeong et al., 2007; Choi et al., 2006a; Choi et al., 2006b), 항균(Won \& Kim, 2012), 항돌연변이 및 항암효과(Kim \& Jang, 2005; Won \& Kim, 2012)가 있다고 보고되고 있으며, 멜라닌 생성억제(Lee, 2009) 효과 가보고되고 있다.

본 연구에서는 인체에 유용한 머루의 안토시아닌 색소가 모발 염색의 염제로서의 가능성을 알아보기 위하여, 염색온도, 염색 시간, $\mathrm{pH}$, 매염제 종류, 매염방법(선매염, 동시매염, 후매염)에 따른 모발염색성을 조사하여 다양한 컬러를 만들어내기 위한 표 준화된 조건을 제시하고자 한다.

\section{Methods}

\section{1. 재료 및 기기}

머루는 지리산 지역에서 재배된 생과를 냉동보관 후 사용 하였으며, 매염제로 사용한 $\mathrm{FeSO}_{4}, \mathrm{MgSO}_{4}, \mathrm{MnSO}_{4}, \mathrm{CuSO}_{4}$, $\mathrm{AlK}\left(\mathrm{SO}_{4}\right)_{2}, \mathrm{CH}_{3} \mathrm{COOH}, \mathrm{Co}\left(\mathrm{NO}_{3}\right)_{2}, \mathrm{CaCO}_{3}, \mathrm{Na}_{2} \mathrm{CO}_{3}$ 와 $\mathrm{pH}$ 조정제로 사용한 $\mathrm{NaOH}, \mathrm{H}_{2} \mathrm{SO}_{4}$ 는 1급시약(Duksan pure chemical, Korea) 을 사용하였다. 1차 증류수(Barnstead Nanopure II Deionization System, USA), 분광측색계(JS-555; Color Techno System Corporation, Japan), $\mathrm{pH}$ 측정기(Thermo Scientific Orion, $\mathrm{USA})$ 를 사용하였으며, 머루 추출은 압착방식의 착즙기(HEDBF04; Hurom, Korea)를 사용하였다.

\section{2. 시료제조}

머루는 냉동 처리된 것을 저온추출법 중 압착법을 적용한 저속 착즙기를 이용하여 분리하여 염재로 사용하였다.

모발시료는 20 세 한국여성으로 질병이 없고 약물복용, 흡연, 염 색이나 펌을 하지 않은 버진헤어(virgin hair)를 모발 전체 길이 약 $23 \mathrm{~cm}$ 중 모근으로부터 10-15 cm를 채취하여 실험에 사용하였다. 시료의 상단 부분을 스와치(swatch)로 글루건(glue gun)을 사용하 여 한 시료 폭당 $1 \mathrm{~cm}$ 길이로 만들어 염색온도별 염색시간과의 염 색성에 15 개, $\mathrm{pH}$ 에 따른 염색성에 8 개, 매염제별 매염방법에 따 른 매염효과에 27 개, 세정견뢰도에 3 개를 제작하였다. 모발시료의 탈색은 파우더 타입의 1 제(프로마스터 파우더 블리치; Hoyu Co. Ltd., Japan)와 6\%의 과산화수소(프로옥사이드; Hoyu Co. Ltd., Japan)를 2제로 사용하여 1제와 2제를 1:1의 비율로 혼합하여 사용 하였다. 실온 $25^{\circ} \mathrm{C}$ 에서 자연방치 후 $30 \mathrm{~min}$ 간격으로 3 회에 걸쳐

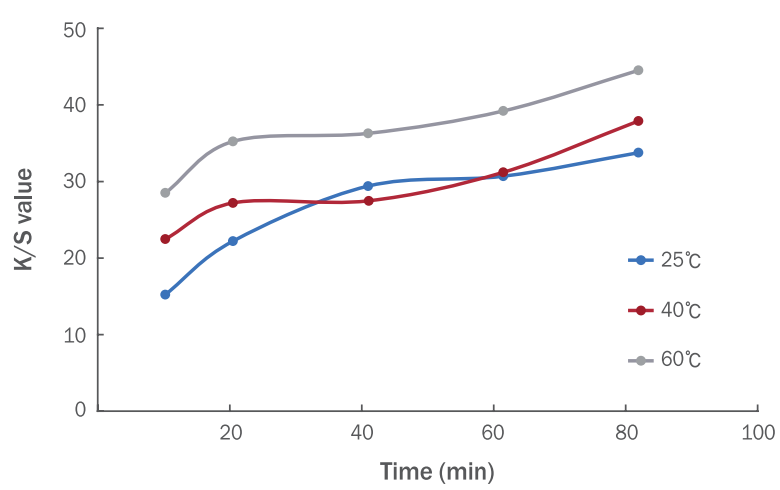

Figure 1. Relationship between $\mathrm{K} / \mathrm{S}$ and dyeing time according to dyeing temperature $\left(25^{\circ} \mathrm{C}, 40^{\circ} \mathrm{C}\right.$ and $\left.60^{\circ} \mathrm{C}\right)$.

The absorbance was measured at $540 \mathrm{~nm}$ using a spectrophotometer. Hair dyeing was increased in dye intake $(\mathrm{K} / \mathrm{S})$ with increased dyeing temperature and time.

명도 10레벨로 탈색시킨 다음 탈색이 끝난 시료는 증류수를 흘려서 수세하고 자연 건조하였다. 탈색된 모발은 진공 팩에 널어 보관 후 시험에 사용하였다.

\section{3. 머루 추출액을 이용한 모발염색}

머루 추출액의 염색 온도와 시간에 따른 모발염색 정도를 알아 보기 위하여 추출액 $15 \mathrm{~mL}$ 에 모발시료를 담구어 항온수조에서 온 도를 $25,40,60^{\circ} \mathrm{C}$ 로 하고 각각 $10,20,40,60,80 \mathrm{~min}$ 동안 염색 한 후 염색된 모발은 흐르는 증류수에 수세하고 자연건조하고 염 색 전, 후 모발시료의 색 변화량을 관찰하기 위하여 분광측색계와 분광측색계 Reader (Ver 1.01; DAEGO Corporation, Korea)를 사 용하여 측정하였다. 분광측색계로 시료의 $\mathrm{X}, \mathrm{Y}, \mathrm{Z}$ 값을 측정하고 $\mathrm{CIE} \mathrm{LAP} \mathrm{색차식을} \mathrm{이용하여} \mathrm{명도(L-Value,} \mathrm{lightness),} \mathrm{적색도}$ (a-Value, redness), 황색도(b-Value, yellowness) 값을 3 회 반복 측정하여 평균값으로 나타내었다.

염착량 측정을 위해서는 염색된 시료 모발을 분광측색계 400-700 $\mathrm{nm}$ 사이에서 $10 \mathrm{~nm}$ 간격으로 측정한 표면 반사율 $\mathrm{R}$ 값을 평균으로 산출하여 Kubelka-Munk 식에 의하여 안토시아닌 색소의 최대흡수 파장에서 K/S (표면염착농도)값을 구하였다(Seo \& Park, 2015).

\section{4. 머루 추출액의 $\mathrm{pH}$ 변화에 따른 모발염색}

머루 추출액 $15 \mathrm{~mL}$ 에 $\mathrm{pH}$ Meter와 $\mathrm{pH}$ 조정제로 $\mathrm{NaOH}$ 와 $\mathrm{H}_{2} \mathrm{SO}_{4}$ 를 사용하여 $\mathrm{pH}$ 3-10 범위로 $\mathrm{pH}$ 를 조정하고, 각각의 $\mathrm{pH}$ 에서 머루 추출액의 최적 염색조건인 염색온도 $25^{\circ} \mathrm{C}$, 염색시간 $40 \mathrm{~min}$ 에서 염색하여 $\mathrm{pH}$ 변화에 따른 모발 색상변화를 관찰하였다.

\section{5. 매염제별 매염방법에 따른 매염효과}

매염제별로 매염방법에 따른 매염효과를 알아보기 위하여 $0.1 \mathrm{M}$ 농도의 몇 가지 매염제 $\left(\mathrm{FeSO}_{4}, \mathrm{MgSO}_{4}, \mathrm{MnSO}_{4}, \mathrm{CuSO}_{4}\right.$, 
$\left.\mathrm{AlK}\left(\mathrm{SO}_{4}\right)_{2}, \mathrm{CH}_{3} \mathrm{COOH}, \mathrm{Co}\left(\mathrm{NO}_{3}\right)_{2}, \mathrm{CaCO}_{3}, \mathrm{Na}_{2} \mathrm{CO}_{3}\right)$ 를 사용하여 선매염, 동시매염, 후매염을 실시한 후 매염효과를 비교하였다. 선매염은 각 매염제별로 $15 \mathrm{~mL}$ 에 탈색된 모발 시료를 담근 후 상온에서 $30 \mathrm{~min}$ 간 매염처리한 후 흐르는 물에 수세하고, 자연 건조한 후 염액 $15 \mathrm{~mL}$ 에 건조된 모발을 담그고 $25^{\circ} \mathrm{C}, 40 \mathrm{~min}$ 간 염색한 후 흐르는 물에 수세하여 자연건조 하였다. 동시매염은 염액 을 비이커에 $15 \mathrm{~mL}$ 를 넣고 각 매염제를 $15 \mathrm{~mL}$ 를 혼합하고 탈색된 모발 시료를 담근 후, $25^{\circ} \mathrm{C}, 40 \mathrm{~min}$ 간 염색한 후 흐르는 물에 수 세하고 자연건조 하였다. 후매염은 염액을 $25^{\circ} \mathrm{C}$ 에서 $40 \mathrm{~min}$ 간 염 색하고 흐르는 물에 수세하여, 자연건조한 후 각 매염제 $15 \mathrm{~mL}$ 에 모발을 담근 후 상온에서 $30 \mathrm{~min}$ 간 자연방치한 후 흐르는 물에 수세하여 자연건조 하였다.

\section{6. 세정견뢰도}

세정견뢰도는 KS K ISO 105-C01의 세탁견뢰도 시험방법을 변 형하여 측정하였다. 시험방법은 염색된 시료모발을 $\mathrm{A}$ 사 컬러전용 삼푸제를 사용하여 물 $500 \mathrm{~mL}$ 에 약 $5 \mathrm{~g}$ 을 희석하여 $3 \mathrm{~min}$ 간 손으 로 세척하고, 수돗물에 좌, 우로 20회씩 흔들어 수세하는 방법으로 세정한 다음 자연건조 후 각각의 시료모발을 색차계로 측정하였다 (Jeon et al., 2011).

\section{Results and Discussion}

\section{1. 머루 추출액의 흡광도 측정}

머루 염액을 희석하여 분광측색계로 400-700 nm 범위에서 흡 광도(absorbance)를 측정한 결과 머루 추출물의 안토시아닌 색소 의 최대흡수파장은 $540 \mathrm{~nm}$ 였다. 천연 추출물에서의 안토시아 닌의 최대흡수파장은 추출물의 종류에 따라 $520 \mathrm{~nm}$ (Hong \& Park, 2013; Kim \& Park, 2014; Shin \& Park, 2014), 540 nm (Jang \& Park, 2015; Lee \& Park, 2012; Seo \& Park, 2015)로 520-540 nm 범주에서 나타나고 있다.

\section{2. 머루 추출액을 이용한 모발염색(무매염)}

1) 염색온도와 염색시간에 따른 모발염색 효과

염색온도 및 염색시간에 따른 염색효과를 알아보기 위해 염 색온도 $25,40,60^{\circ} \mathrm{C}$ 에서 각각의 염색 온도별로 염색시간을 10 , $20,40,60,80 \mathrm{~min}$ 으로 하여 포도껍질 추출물의 K/S (표면염착 농도; 염착량) 값 및 $\mathrm{L}^{*}$ (명도), $\mathrm{a}^{*}$ (적색도), $\mathrm{b}^{*}$ (황색도) 값을 나 타내었다(Table 1-Table 3).

이때 실험에 사용한 탈색된 모발시료의 $\mathrm{L}^{*}$ 값은 $22.697, \mathrm{a}^{*}$ 값은 $0.446, \mathrm{~b}^{*}$ 값은 6.664 그리고 $\mathrm{K} / \mathrm{S}$ 값은 12.697 이였다. 머루 추 출물의 안토시아닌 색소는 염색온도 $25,40,60^{\circ} \mathrm{C}$ 에서 염색시 간이 증가할수록 $\mathrm{K} / \mathrm{S}$ 값은 증가(Kim \& Park, 2014; Jang \&
Park, 2015; Seo \& Park, 2015)하여 염착량이 증가하는 것으 로 나타났다(Figure 1).

머루 추출액의 $\mathrm{K} / \mathrm{S}$ 값은 15.229-44.519로 나타났다. 이 결과 는 동일한 추출법을 사용한 아로니아의 $\mathrm{K} / \mathrm{S}$ 값인 68.255-76.266 (Kim \& Park, 2014), 블랙베리의 K/S 값인 39.848-61.369 (Shin $\&$ Park, 2014), 포도껍질의 K/S 값인 25.557-55.726 (Seo \& Park, 2015), 버찌의 K/S 값인 24.099-64.173 (Hong \& Park, 2013)보다 는 상대적으로 낮게 나타났으며, 오디의 K/S 값인 11.740-36.700 (Jang \& Park, 2015) 보다는 높은 염착도를 나타냈다.

이결과를바탕으로 $25,40,60^{\circ} \mathrm{C}$ 에서 염색시간이증가함에 따라 $L^{*}$ 값 과 $\mathrm{K} / \mathrm{S}$ 값의 증가폭이 큰 염색온도 $25^{\circ} \mathrm{C}$, 염색시간 $40 \mathrm{~min}$ 을 표준 염 색조건으로 결정하고 실험을 진행하였다. 이 결과는 블랙베리(Shin $\&$ Park, 2014)와 아로니아(Kim \& Park, 2014)의 결과와 일치한다.

Table 1. Colorimeter values of hair dyed with extracts of wild grape in diverse dyeing time at $25^{\circ} \mathrm{C}$

\begin{tabular}{lcccc}
\hline & $\mathrm{L}^{*}$ & $\mathrm{a}^{*}$ & $\mathrm{~b}^{*}$ & $\mathrm{~K} / \mathrm{S}$ \\
$10 \mathrm{~min}$ & 22.725 & 6.698 & -3.588 & 15.229 \\
$20 \mathrm{~min}$ & 17.532 & 4.149 & -2.949 & 22.209 \\
$40 \mathrm{~min}$ & 15.379 & 5.943 & -2.694 & 29.402 \\
$60 \mathrm{~min}$ & 14.598 & 4.886 & -2.898 & 30.691 \\
$80 \mathrm{~min}$ & 13.654 & 5.078 & -2.754 & 33.760 \\
\hline
\end{tabular}

$L^{*}$ : Lightness (0-100), a : CIE LAB-redness ( $\left.\pm a\right), b^{*}$ : CIE LAB-yellowness $( \pm b), K / S$ : dye intake

Table 2. Colorimeter values of hair dyed with extracts of wild grape in diverse dyeing time at $40^{\circ} \mathrm{C}$

\begin{tabular}{ccccc}
\hline & $\mathrm{L}^{*}$ & $\mathrm{a}^{*}$ & $\mathrm{~b}^{*}$ & $\mathrm{~K} / \mathrm{S}$ \\
\hline $10 \mathrm{~min}$ & 17.958 & 5.605 & -3.205 & 22.482 \\
$20 \mathrm{~min}$ & 16.883 & 8.088 & -4.002 & 27.204 \\
$40 \mathrm{~min}$ & 15.963 & 5.433 & -2.117 & 27.473 \\
$60 \mathrm{~min}$ & 14.474 & 4.878 & -2.060 & 31.202 \\
$80 \mathrm{~min}$ & 13.060 & 7.141 & -2.550 & 37.905 \\
\hline
\end{tabular}

$L^{*}$ : Lightness (0-100), a : CIE LAB-redness ( $\left.\pm a\right), b^{*}:$ CIE LAB-yellowness $( \pm b), K / S$ : dye intake

Table 3. Colorimeter values of hair dyed with extracts of wild grape in diverse dyeing time at $60^{\circ} \mathrm{C}$

\begin{tabular}{ccccc}
\hline & $\mathrm{L}^{*}$ & $\mathrm{a}^{*}$ & $\mathrm{~b}^{*}$ & $\mathrm{~K} / \mathrm{S}$ \\
\hline $10 \mathrm{~min}$ & 16.019 & 7.603 & -2.221 & 28.503 \\
$20 \mathrm{~min}$ & 14.122 & 7.579 & -1.447 & 35.234 \\
$40 \mathrm{~min}$ & 13.061 & 4.866 & -1.097 & 36.288 \\
$60 \mathrm{~min}$ & 12.486 & 5.503 & -0.832 & 39.213 \\
$80 \mathrm{~min}$ & 11.036 & 4.117 & -0.752 & 44.519 \\
\hline
\end{tabular}

$L^{*}$ : Lightness (0-100), a*: CIE LAB-redness ( $\left.\pm a\right), b^{*}$ : CIE LAB-yellowness $( \pm \mathrm{b}), \mathrm{K} / \mathrm{S}$ : dye intake 
Table 4. Colorimeter values of hair dyed with wild grape in diverse dyeing $\mathrm{pH}\left(25^{\circ} \mathrm{C}, 40 \mathrm{~min}\right)$

\begin{tabular}{|c|c|c|c|c|}
\hline & $\mathrm{L}^{*}$ & $a^{*}$ & $b^{*}$ & $\mathrm{~K} / \mathrm{S}$ \\
\hline Not pH control dyeing fluid (3.97) & 15.379 & 5.943 & -2.694 & 29.402 \\
\hline $\mathrm{pH} 3$ & 9.631 & 5.509 & -1.735 & 56.722 \\
\hline $\mathrm{pH} 4$ & 11.287 & 4.289 & -2.627 & 44.626 \\
\hline $\mathrm{pH} 5$ & 10.459 & 2.603 & -2.189 & 46.523 \\
\hline $\mathrm{pH} 6$ & 11.623 & 1.070 & -1.018 & 38.278 \\
\hline $\mathrm{pH} 7$ & 12.794 & 0.838 & -0.659 & 32.718 \\
\hline $\mathrm{pH} 8$ & 15.937 & -0.123 & 1.943 & 23.351 \\
\hline $\mathrm{pH} 9$ & 16.886 & -0.162 & 3.700 & 21.708 \\
\hline pH 10 & 17.739 & 0.214 & 4.510 & 20.097 \\
\hline
\end{tabular}

L*: Lightness (0-100), a*: CIE LAB-redness ( $\pm a), b^{*}:$ CIE LAB-yellowness ( $\left.\pm b\right), K / S$ : dye intake

Table 5. Colorimeter values of hair dyed with extracts of wild grape in diverse mordanting method $\left(25^{\circ} \mathrm{C}, 40 \mathrm{~min}\right)$

\begin{tabular}{|c|c|c|c|c|c|}
\hline Mordant & Mordanting method & $L^{*}$ & $a^{*}$ & $b^{*}$ & $\mathrm{~K} / \mathrm{S}$ \\
\hline \multirow{3}{*}{$\mathrm{FeSO}_{4}$} & Pre-mordanting & 9.149 & 1.447 & -2.384 & 52.910 \\
\hline & Simultaneous mordanting & 9.549 & 0.323 & -0.598 & 47.123 \\
\hline & Post-mordanting & 10.732 & 0.632 & -1.840 & 42.130 \\
\hline \multirow{3}{*}{$\mathrm{MgSO}_{4}$} & Pre-mordanting & 9.958 & 3.212 & -1.413 & 49.796 \\
\hline & Simultaneous mordanting & 9.902 & 2.210 & -0.899 & 49.460 \\
\hline & Post-mordanting & 17.174 & 5.010 & -1.170 & 24.865 \\
\hline \multirow{3}{*}{$\mathrm{MnSO}_{4}$} & Pre-mordanting & 10.512 & 5.073 & -1.989 & 50.137 \\
\hline & Simultaneous mordanting & 13.299 & 1.760 & 0.813 & 32.037 \\
\hline & Post-mordanting & 13.223 & 2.759 & -0.356 & 32.768 \\
\hline \multirow{3}{*}{$\mathrm{CuSO}_{4}$} & Pre-mordanting & 10.795 & 2.254 & -3.353 & 44.176 \\
\hline & Simultaneous mordanting & 11.881 & 0.441 & -0.776 & 35.694 \\
\hline & Post-mordanting & 10.825 & 2.879 & -4.698 & 44.809 \\
\hline \multirow{3}{*}{$\operatorname{AlK}\left(\mathrm{SO}_{4}\right)_{2}$} & Pre-mordanting & 14.906 & 6.004 & -5.019 & 31.199 \\
\hline & Simultaneous mordanting & 14.508 & 5.223 & -3.321 & 31.382 \\
\hline & Post-mordanting & 10.480 & 1.847 & -3.363 & 44.809 \\
\hline \multirow{3}{*}{$\mathrm{CH}_{3} \mathrm{COOH}$} & Pre-mordanting & 13.502 & 8.260 & -1.733 & 40.412 \\
\hline & Simultaneous mordanting & 16.588 & 7.446 & -2.485 & 27.758 \\
\hline & Post-mordanting & 12.449 & 7.423 & -1.275 & 42.791 \\
\hline \multirow{3}{*}{$\mathrm{Co}\left(\mathrm{NO}_{3}\right)_{2}$} & Pre-mordanting & 11.372 & 4.082 & -1.310 & 44.705 \\
\hline & Simultaneous mordanting & 17.441 & 5.001 & -0.003 & 22.944 \\
\hline & Post-mordanting & 13.689 & 3.971 & -1.212 & 33.843 \\
\hline \multirow{3}{*}{$\mathrm{CaCO}_{3}$} & Pre-mordanting & 15.703 & 5.966 & -1.560 & 30.036 \\
\hline & Simultaneous mordanting & 15.624 & 1.566 & -1.256 & 25.512 \\
\hline & Post-mordanting & 11.895 & 0.794 & 0.131 & 36.486 \\
\hline \multirow{3}{*}{$\mathrm{Na}_{2} \mathrm{CO}_{3}$} & Pre-mordanting & 11.942 & 6.044 & -2.318 & 44.705 \\
\hline & Simultaneous mordanting & 17.238 & -0.142 & 3.757 & 20.062 \\
\hline & Post-mordanting & 22.854 & 1.525 & 8.828 & 13.275 \\
\hline
\end{tabular}

$L^{*}$ : Lightness (0-100), a*: CIE LAB-redness ( $\left.\pm a\right), b^{*}$ : CIE LAB-yellowness $( \pm b), K / S$ : dye intake 
2) $\mathrm{pH}$ 에 따른 모발 염착성과 측색효과

모발염색 시 머루 추출물의 안토시아닌 색소는 $\mathrm{pH} 3$ 에서 는 $\mathrm{K} / \mathrm{S}$ 값이 56.722 로 최고로 염착도가 높아 밝고 진한 적 자색을 나타냈다. $\mathrm{pH}$ 가 증가함에 따라 $\mathrm{a}^{*}$ 값이 지속적으로 감소하여 적색이 감소하였으며, $\mathrm{pH}$ 8-10에서는 안토시아 닌 색소의 본래의 색이 퇴색하며 $\mathrm{b}^{*}$ 값이 증가하여 황색을 띄게 되었다(Table 4). 이로서 안토시아닌 색소는 $\mathrm{pH}$ 에 특 히 민감하게 반응하며, $\mathrm{pH}$ 가 증가함에 따라 전체적으로 염 착성이 감소하고 염착이 불량하게 되어 염색의 효과를 기대 할 수 없게 되었다(Seo \& Park, 2015; Jang \& Park, 2015).

\section{3. 매염방법에 따른 매염제의 모발염색}

매염제를 이용한 매염방법에 따른 $\mathrm{K} / \mathrm{S}$ 값은 $\mathrm{FeSO}_{4}$, $\mathrm{MgSO}_{4}, \mathrm{Na}_{2} \mathrm{CO}_{3}$ 에서 선매염>동시매염>후매염 순이였으 며, $\mathrm{CuSO}_{4}, \mathrm{CH}_{3} \mathrm{COOH}, \mathrm{CaCO}_{3}$ 는 동시매염>후매염>선매 염 순이었다. $\mathrm{MnSO}_{4}, \mathrm{Co}\left(\mathrm{NO}_{3}\right)_{2}$ 는 선매염>후매염 동시매 염 순이었으며, $\mathrm{AlK}\left(\mathrm{SO}_{4}\right)_{2}$ 는 후매염 동시매염>선매염 순 으로 나타났다(Table 5).

$\mathrm{FeSO}_{4}$ 은 선매염 시 보랏빛이 포함된 진한 검정색으로 백모 의 진한 염색에 적합하였고, 동시매염 시 진한 갈색을 나타내 었다. $\mathrm{AlK}\left(\mathrm{SO}_{4}\right)_{2}$ 는 후매염 시 밝은 보라색을 나타내었으며, 선매염과 동시매염에서는 진한 적자색을 나타내었다. $\mathrm{CuSO}_{4}$ 는 후매염 시 진한 보라색을 나타내었다. $\mathrm{MgSO}_{4}, \mathrm{MnSO}_{4}$ 는 선매염에서는 밝은 적자색을 나타내었으며, $\mathrm{CH}_{3} \mathrm{COOH}$ 은 모든 매염법에서 밝은 적색이 나타났다. $\mathrm{Co}\left(\mathrm{NO}_{3}\right)_{2}$ 는 선 매염에서 엷게 밝은 적자색이 나타났으며, 알칼리성 매염제 인 $\mathrm{CaCO}_{3}, \mathrm{Na}_{2} \mathrm{CO}_{3}$ 는 선매염에서는 탁한 적색이 나타났으나, 후매염 시 알칼리성에 의한 안토시아닌 색소의 본래의 색이 퇴색하여 $\mathrm{CaCO}_{3}$ 는 염색효과를 기대하기 힘들었다.

\section{4. 세정견뢰도}

머루 추출물을 이용하여 염색온도 $25^{\circ} \mathrm{C}$, 염색시간 40 $\min$ 에서 모발염색한 시료모발 3 개를 $5,10,15,20$ 회 삼 푸한 결과 세정횟수가 증가함에 따라 $\mathrm{K} / \mathrm{S}$ 값이 감소하였다 (Figure 2).

머루 추출물의 경우 $\mathrm{K} / \mathrm{S}$ 값은 43.909-16.748로 세정 후 $\mathrm{K} / \mathrm{S}$ 값 차는 평균 22.272 로 나타났다. 이 결과는 오디 추출 물의 8.342, 아로니아 추출물의 17.210 보다는 크게 나타났으 며, 포도껍질 추출물의 31.917 , 블랙베리 추출물에서 47.406 보다는 낮게 나타났다(Seo \& Park, 2015). 머루 추출물의 경 우 무매염 시에도 $\mathrm{K} / \mathrm{S}$ 값이 높아 모발염료로 사용이 가능하였 으나, 세정 시 $\mathrm{K} / \mathrm{S}$ 값의 큰 차이로 무매염 시 모발 염료로 사용 하려면 매염제의 사용이 필요할 것이라 사료된다.

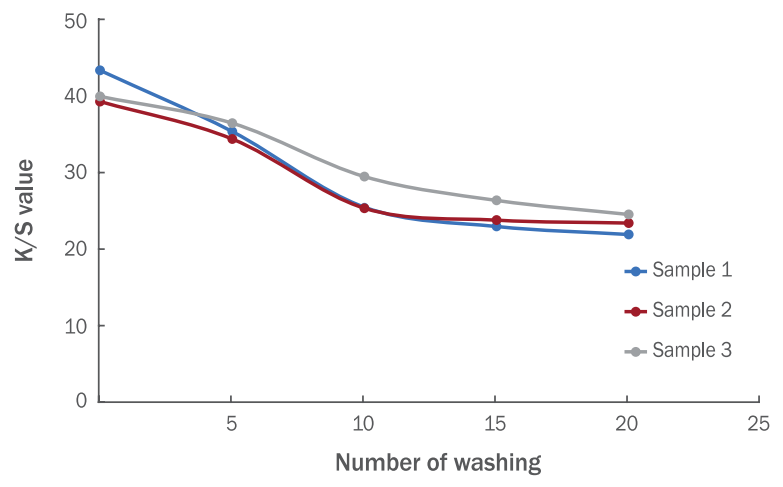

Figure 2. Changes of color difference (K/S) of dyed hair with extract from wild grape as washing sampoo.

The absorbance was measured at $540 \mathrm{~nm}$ using a spectrophotometer. The rate of colorfastness was decreased with repeating shampoo washing.

\section{Conclusion}

머루 추출물의 안토시아닌 색소를 이용한 모발 천연염 색에서 염색온도, 염색시간 및 $\mathrm{pH}$ 를 변화시켜가며 염착도 와 색변화를 관찰하였으며, 몇 가지 매염제를 사용하여 매 염방법에 따른 매염효과와 세정견뢰도를 관찰하였다. 모발 염색 시 염색온도 $\left(20-60^{\circ} \mathrm{C}\right)$ 가 증가함에 따라 염착량 $(\mathrm{K} / \mathrm{S})$ 도 증가하였고, 머루 추출물은 염색온도 $25^{\circ} \mathrm{C}$, 염색시간 $40 \mathrm{~min}$ 에서 염색이 적당하였다. 안토시아닌 염제가 $\mathrm{pH}$ 에 특히 민감하게 반응하고 대부분 $\mathrm{pH}$ 가 증가함에 따라 염 착성은 급격히 감소하였다. 산성에서는 $\mathrm{a}^{*}$ 값이 증가하고, 알칼리에서는 $b^{*}$ 값이 증가하는 것으로 나타났다. 모발 염 색 시 매염방법(선매염, 동시매염, 후매염)은 매염제의 특 성(염착량, 명도, 채도, 색상)을 전체적으로 고려하여 선 택해야 한다. 염착량 $(\mathrm{K} / \mathrm{S})$ 만을 기준으로 본다면 선매염은 $\mathrm{FeSO}_{4}, \mathrm{MgSO}_{4}, \mathrm{Na}_{2} \mathrm{CO}_{3}, \mathrm{MnSO}_{4}, \mathrm{Co}\left(\mathrm{NO}_{3}\right)_{2}$ 에, 동시매염 은 $\mathrm{CuSO}_{4}, \mathrm{CH}_{3} \mathrm{COOH}, \mathrm{CaCO}_{3}$ 에, 후매염은 $\mathrm{AlK}\left(\mathrm{SO}_{4}\right)_{2}$ 에 효과적이었다. 컬러 전용 삼푸제를 사용하여 20회 반복 세 정 시 염착량 차는 평균 22.272 감소하였다.

이상의 연구결과 머루 추출물의 안토시아닌 색소는 인 간의 모발에 적용 가능한 천연염모제로서의 가능성을 가 지고 있으며, 매염제 사용시 다양한 색상 구현 및 염착도 를 향상시킬 수 있어 천연 다색성 염료로 사용이 가능하리 라 사료된다. 


\section{References}

Ali S, Hussain T, Nawaz R. Optimization of alkaline extraction of natural dye from Henna leaves and its dyeing on cotton by exhaust method. Journal of Cleaner Production, 17: 61-66, 2009.

Bing DJ, Lee JH, Chun SS. Quality characteristics and antioxidant activity of salad dressings prepared with wild grape powder during storage. Journal of the Korean Society of Food Science and Nutrition, 44: 250-259, 2015.

Bomser J, Madhavi DL, Singletary K, Smith MA. In vitro anticancer activity of fruit extracts from Vaccinium species. Planta Medica, 62: 212-216, 1996.

Choi SY, Cho HS, Kim HJ, Ryu CH, Lee JO, Sung NJ. Physicochemical analysis and antioxidative effects of wild grape (Vitis coignetiea) juice and its wine. The Korean Journal of Food and Nutrition, 19: 311-317, $2006 a$.

Choi SY, Cho HS, Sung NJ. The antioxidative and nitrite scavenging ability of solvent extracts from wild grape (Vitis coignetiea) skin. Journal of the Korean Society of Food Science and Nutrition, 35: 961-966, 2006b.

Choi IR, Kim YJ. A study on dyeing and weighting effect of silk using natural dye: focus on the Rhus. javanica. L. $\&$ green tea. The Journal of Living Culture Research, 18: 1-26, 2004.

Hong GO, Park $\mathrm{CH}$. Hair dyeing properties by using extracts of Prunus pauciflorat. Journal of the Korean Society of Cosmetology, 19: 945-951, 2013.

Hou DX. Potential mechanisms of cancer chemoprevention by anthocyanins. Current Molecular Medicine, 3: 149159, 2003.

Jang AS, Park CH. A study on the hair dyeing and colorfastness using extracts of mulberry. Asian Journal of Beauty and Cosmetology, 13: 237-242, 2015.

Jeon AR, Kim SY, Choi HJ, Na MS. Human hair dyed and colorfastness of hot water extract from Gallnut. Journal of the Korean Society of Cosmetology, 17: 87-93, 2011.

Jung IC, Moon YH. Effects on quality characteristics of pork loin fed with wild grape (Vitis amurensis Ruprecht) wine by-product. Korean Journal for Food Science of Animal Resources, 25: 168-174, 2005.
Jeong HJ, Park SB, Kim S, Kim HK. Total polyphenol content and antioxidative activity of wild grape (Vitis coignetiae) extracts depending on ethanol concentrations. Journal of the Korean Society of Food Science and Nutrition, 36: 1491-1496, 2007.

Kamei H, Kojima T, Hasegawa M, Koide T, Umeda T, Yukawa T, Terabe K. Suppression of tumor cell growth by anthocyanins in vitro. Cancer Investigation, 13: 590594, 1995.

Kang NK, Kim SN. A study on change of hair according to former treatment when hair dyeing is treated. Journal of the Korean Beauty Art Society, 2: 109-119, 2008.

Kim JY, Park CH. Hair dyeing properties using extracts of Aronia melancocarpa. Asian Journal of Beauty and Cosmetology, 12: 663-668, 2014.

Kim MJ, Jang MS. Quality characteristics of sponge cakes with addition of corn starch. Journal of the Korean Society of Food Science and Nutrition, 34: 1427-1433, 2005.

Kim NY, Kim YK, Bae KJ, Choi JH, Moon JH, Park GH, Oh $\mathrm{DH}$. Free radical scavenging effect and extraction condition of ethanol extracts and fractions of wild grape seed (Vitis coignetiea). Journal of the Korean Society of Food Science and Nutrition, 34: 755-758, 2005.

Kim SK. Deacidification of new wild grape wine. The Korean Journal of Food and Nutrition, 9: 265-270, 1996.

Lee JR, Park $\mathrm{CH}$. Natural hair dyeing using a black soybean seed coat. Journal of Investigative Cosmetology, 8: 127-134, 2012.

Lee P. Inhibitory effect of muscat bailey a seed extract on melanin production in $\alpha$-melanin stimulating hormone-stimulated B16 cell. Korean Journal of Plant Resources, 22: 477-482, 2009.

Nagase H, Sasaki K, Kito H, Haga A, Sato T. Inhibitory effect of delphinidin from Solanum melongena on human fibrosarcoma HT-1080 invasiveness in vitro. Planta Medica, 64: 216-219, 1998.

Noda Y, Kaneyuki T, Mori A, Packer L. Antioxidant activities of pomegranate fruit extract and its anthocyanidins: delphinidin, cyanidin, and pelargonidin. Journal of Agricultural and Food Chemistry, 50: 166-171, 2002.

Park HS. The antioxidant and nitrite scavenging activity of wild grape (Vitis coignetiea) wine. Journal of the 
East Asian Society of Dietary Life, 21: 68-73, 2011a.

Park HS. Antioxidant activity of solvent extracts from Vitis coignetiea skins. The Korean Journal of Culinary Research, 17: 208-217, 2011b.

Seo JC, Park CH. A study on the hair dyeing properties by using extracts of grape skin. Asian Journal of Beauty and Cosmetology, 13: 689-694, 2015.

Shin DY, Lee WS, Lu JN, Kang MH, Ryu CH, Kim GY, Kang HS, Shin SC, Choi YH. Induction of apoptosis in human colon cancer HCT-116 cells by anthocyanins through suppression of Akt and activation of p38-MAPK. International Journal of Oncology, 35: 1499-1504, 2009.

Shin HN, Park $\mathrm{CH}$. A study on the hair dyeing properties by using extracts of Rubus fruticosus. Journal of the Korean Society of Cosmetology, 20: 30-35, 2014.

Tsuda T, Shiga K, Ohshima K, Kawakishi S, Osawa T. Inhibition of lipid peroxidation and the active oxygen radical scavenging effect of anthocyanin pigments isolated from Phaseolus vulgaris L. Biochemical Pharmacology, 52: 1033-1039, 1996.
Wang $\mathrm{H}$, Nair MG, Strasburg GM, Chang YC, Booren AM, Gray JI, DeWitt DL. Antioxidant and antiinflammatory activities of anthocyanins and their aglycon, cyanidin, from tart cherries. Journal of Natural Products, 62: 294-296, 1999.

Won JH, Kim M. Analysis of antibacterial activity against food spoilage and food-borne pathogens and cytotoxicity on human cancer cell lines of extracts from pericarp and seed of Vitis coignetiea. Korean Journal of Food and Cookery Science, 28: 175-182, 2012.

Won HR. Effect of wild grape juice on lipid metabolism and antioxidative activity in rat fed high oxidized lipid. The Korean Journal of Community Living Science, 20: 223230, 2009. 


\section{국문초록}

\section{머루(Vitis coignetiae) 추출물을 이용한 모발 염색 특성}

최윤영, 박철호"

남부대학교 향장미용학과, 광주, 한국

목적: 본 연구는 머루 추출물의 안토시아닌 색소를 이용한 모발의 천연염색 가능성을 알아보고자 하였다. 방법: 안토시아닌 의 최대흡수파장인 $540 \mathrm{~nm}$ 에서 염색온도, 염색시간 및 $\mathrm{pH}$ 를 변화시켜가며 염착도와 색변화를 관찰하였으며, 몇 가지 매염 제를 사용하여 매염방법에 따른 매염효과와 세정견뢰도를 관찰하였다. 결과: 모발 염색 시 염색온도가 증가함에 따라 염착 량 $(\mathrm{K} / \mathrm{S})$ 도 증가하였고, 머루 추출물은 염색온도 $25^{\circ} \mathrm{C}$, 염색시간 40 분에서 염색이 적당하였다. 안토시아닌 염제가 $\mathrm{pH}$ 에 특 히 민감하게 반응하고 대부분 $\mathrm{pH}$ 가 증가함에 따라 염착성은 급격히 감소하였다. 산성에서는 $\mathrm{a}^{*}$ 값이 증가하고, 알칼리성에 서는 $b^{*}$ 값이 증가하는 것으로 나타났다. 모발 염색 시 매염방법(선매염, 동시매염, 후매염)은 매염제의 특성(염착량, 명도, 채도, 색상)을 전체적으로 고려하여 선택해야 한다. 염착량 $(\mathrm{K} / \mathrm{S})$ 만을 기준으로 본다면 선매염은 $\mathrm{FeSO}_{4}, \mathrm{MgSO}_{4}, \mathrm{Na}_{2} \mathrm{CO}_{3}$, $\mathrm{MnSO}_{4}, \mathrm{Co}\left(\mathrm{NO}_{3}\right)_{2}$ 에, 동시매염은 $\mathrm{CuSO}_{4}, \mathrm{CH}_{3} \mathrm{COOH}, \mathrm{CaCO}_{3}$ 에, 후매염은 $\mathrm{AlK}\left(\mathrm{SO}_{4}\right)_{2}$ 에 효과적이었다. 컬러 전용 삼푸제를 사용하여 20회 반복 세정 시 염착량 차는 평균 22.272 감소하였다. 결론: 이상의 연구결과, 머루 추출물의 안토시아닌 색소 는 인간의 모발에 적용 가능한 천연염모제로서의 가능성을 가지고 있으며, 매염제 사용시 다양한 색상 구현 및 염착도를 향 상시킬 수 있어 천연 다색성 염료로 사용이 가능하리라 사료된다.

핵심어: 머루, 염색, 안토시아닌, 매염제, 세정견뢰도

\section{참고문헌}

강나경, 김성남. 헤어염색 시 전처리에 따른 모발의 변화에 대한 연구. 한국미용예술학회지, 2: 109-119, 2008.

김난영, 김영국, 배기자, 최재호, 문제학, 박근형, 오덕환. 머루종자의 적정 추출조건 및 추출 분획물의 Free Radical 소거능

효과. 한국식품영양과학회지, 34: 755-758, 2005.

김미정, 장명숙. 옥수수 전분을 첨가한 스폰지 케이크의 품질특성. 한국식품영양과학회지, 34: 1427-1433, 2005.

김승겸. 개량머루주의 감산에 관한 연구. 한국식품영양학회지, 9: 265-270, 1996.

김주영, 박철호. 아로니아(Aronia melancocarpa) 추출물을 이용한 모발의 염색 특성. 아시안뷰티화장품학술지, 12: 663-

668, 2014.

박현실. 머루와인의 항산화성 및 아질산염 소거능. 동아시아식생활학회지, 21: 68-73, 2011a.

박현실. 용매별 머루 과피 추출물의 항산화 효과. 한국조리학회지, 17: 208-217, 2011b.

빙동주, 이지현, 전순실. 머루 분말을 첨가한 샐러드드레싱의 저장 중 품질 특성과 항산화 활성. 한국식품영양과학회지, $44:$

250-259, 2015.

서종철, 박철호. 포도껍질 추출물을 이용한 모발의 염색 특성. 아시안뷰티화장품학술지, 13: 689-694, 2015.

신화남, 박철호. 블랙베리(Rubus fruticosus) 추출물을 이용한 모발의 염색특성. 한국미용학회지, 20: 30-35, 2014.

이정례, 박철호. 검정콩 종피를 이용한 모발의 천연염색. 대한미용학회지, 8: 127-134, 2012.

이평재. 머루포도 씨 추출물의 $\alpha$-Melanin Stimulating Hormone으로 자극한 B16세포에서 melanin 생성억제 효과. 한국자

원식물학회지, 22: 477-482, 2009.

원지혜, 김미라. 머루 과피와 종자 추출물의 식품 위해성 세균에 대한 항균성 및 인체 암세포주에 대한 cytotoxicity 분석. 한국

식품조리과학회지, 28: 175-182, 2012.

원향례. 산화된 지방식이를 급여한 흰쥐에서의 머루즙 투여가 지질대사와 항산화에 미치는 영향. 한국지역사회생활과학회지, 
20: 223-230, 2009.

장애선, 박철호. 오디(Mulberry) 추출물의 모발 염색 및 견뢰도 연구. 아시안뷰티화장품학술지, 13: 237-242, 2015.

전아름, 김수영, 최희진, 나명석. 오배자(Gallnut) 열수 추출물의 모발염색 및 염색견뢰도. 한국미용학회지, 17: 87-93, 2011. 정인철, 문윤희. 머루주 박의 급여가 돈육 등심의 품질에 미치는 영향. 한국축산식품학회지, 25: 168-174, 2005.

정현진, 박선빈, 김선아, 김현구. 에탄올 농도에 따른 머루(Wild grape, Vitis coignetiae) 추출물의 폴리페놀 함량 및 항산화 활성. 한국식품영양과학회지, 36: 1491-1496, 2007.

최선영, 조현소, 김행자, 류충호, 이정옥, 성낙주. 머루즙과 머루주의 이화학적 분석 및 항산화 효과. 한국식품영양학회지, $19:$ 311-317, 2006a.

최선영, 조현소, 성낙주. 머루 과피 용매추출물의 항산화성 및 아질산염 소거작용. 한국식품영양과학회지, 35: 961-966, 2006b. 최인려, 김연주. 천연염료를 이용한 견섬의 염색성 및 증량효과 연구: 오배자와 녹차를 중심으로. 생활문화연구, 18: 1-26, 2004. 홍경옥, 박철호. 버찌(Prunus pauciflora) 추출물을 이용한 모발의 염색특성. 한국미용학회지, 19: 945-951, 2013. 


\section{中文摘要}

\section{利用野生葡萄提取物研究染发特性}

崔允寧，朴哲浩"

南部大學校香妝美容學科，光州，韩国

目的: 利用野生葡萄的花色苷色素（anthocyanin）探讨天然染发剂的可行性。方法: Anthocyanin的最大吸收波长为 $540 \mathrm{~nm}$, 根据温度、时间及pH值的变化, 观察竭染率（degree of exhaustion）及颜色变化。利用几种媒染剂根据不 同媒染方法观察媒染效果和洗色牢度。结果: 染发时, 随着温度的升高, 染色量 (K/S) 也随着增加, 野生葡萄提取物 在温度 $25^{\circ} \mathrm{C}$, 染色时间为 $40 \mathrm{~min}$ 时, 染色效果最为恰当。Anthocyanin 媒染剂对 $\mathrm{pH}$ 值特别敏感, 大部分随着 $\mathrm{pH}$ 值的 增加, 染色性急速降低。在酸性条件下, a“值增加, 碱性条件下, b“值增加。染发时, 需从整体考虑媒染剂的特性 （染色量、明度、彩度、颜色）后，再选择媒染方法（列如，预媒染，同时媒染，后媒染）。按照染色量（K/S）考 虑, 有效的方法是预媒染为 $\mathrm{FeSO}_{4}, \mathrm{MgSO}_{4}, \mathrm{Na}_{2} \mathrm{CO}_{3}, \mathrm{MnSO}_{4}, \mathrm{Co}\left(\mathrm{NO}_{3}\right)_{2}$, 同时媒染为 $\mathrm{CuSO}_{4}, \mathrm{CH}_{3} \mathrm{COOH}, \mathrm{CaCO}_{3}$, 后媒染为AIK $\left(\mathrm{SO}_{4}\right)_{2}$ 。利用专用洗发水反复清洗20次后染色量平均减少 22.272 。结论: 从以上的研究结果中得出, 野生 葡萄的 anthocyanin可以作为天然染发剂使用, 作为媒染剂使用时, 可以展现多种颜色, 也可提高竭染率, 因此可以作 为天然多色性染料使用。

关键词: 野生葡萄, 染色, 花色苷色素, 媒染剂, 洗色牢度 